\title{
ANALYSIS OF RESIDUAL ORGANIC MATERIALS IN AQUEOUS RADIOACTIVE STREAMS FROM
}

\section{THE PUREX PROCESS}

H. E, SHOOK, JR.

\section{Approved by}

E. W. Holtzscheiter, Research Manager

Actinide Technology Division

Publication Date: May 1987

\author{
Actinide Technology Division
}

\section{DISCLAIMER}

\begin{abstract}
This report was prepared as an account of work sponsored by an agency of the United States employees, makes any warranty States Government nor any agency thereof, nor any of their bility for the accuracy, completenespress or implied, or assumes any legal liability or responsiprocess disclosed, or represents that its use woss of any information, apparatus, product, or ence herein to any specific commercial product process, infinge privately owned rights. Refermanufacturer, or otherwise does not product, process, or service by trade name, trademark, mendation, or favoring by the United States Governmentite or imply its endorsement, reconand opinions of authors the United States Government or any agency thereof. The views

United States Government or any agency thereof.
\end{abstract} \\ DE87 010562}




\section{DISCLAIMER}

This report was prepared as an account of work sponsored by an agency of the United States Government. Neither the United States Government nor any agency Thereof, nor any of their employees, makes any warranty, express or implied, or assumes any legal liability or responsibility for the accuracy, completeness, or usefulness of any information, apparatus, product, or process disclosed, or represents that its use would not infringe privately owned rights. Reference herein to any specific commercial product, process, or service by trade name, trademark, manufacturer, or otherwise does not necessarily constitute or imply its endorsement, recommendation, or favoring by the United States Government or any agency thereof. The views and opinions of authors expressed herein do not necessarily state or reflect those of the United States Government or any agency thereof. 


\section{DISCLAIMER}

Portions of this document may be illegible in electronic image products. Images are produced from the best available original document. 


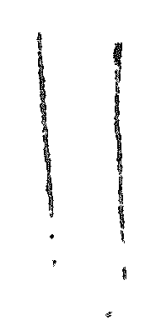


New solid phase extraction methods have been developed to allow determination of residual normal paraffin hydrocarbon (NPH) and tri-n-butyl phosphate (TBP) in aqueous radioactive streams from the Purex process. The techniques concentrate organic materials and separate them from radioactive species for analysis by gas chromatography.

TBP and NPH have good radiolytic and chemical stability and have low aqueous solubility. However, they can contaminate aqueous streams and cause processing difficulties. Knowledge of the concentration of organic materials in aqueous waste is useful in assessing impact on pollution control equipment. The storage quality of diluent-washed aqueous plutonium product solution can be determined by a gas chromatographic analysis for residual TBP. 
. 
Page

Introduction

Purex Process Description

Sampling and Experimental Method

Results and Discussion

Conclusions

References 



$\begin{array}{llr}1 & \text { Stream Sampling } & \text { Page } \\ 2 & \text { Recoveries of NPH and TBP with Baker C-18 Columns } & 11 \\ 3 & \text { Recoveries of NPH and TBP with Supelco C-18 Colums } & 13 \\ 4 & \text { NPH and TBP Concentrations in Composite Aqueous Waste } & 14 \\ 5 & \text { Recovery of TBP (Concentration Factor }=5 \text { ) } & 15 \\ 6 & \text { Recovery of TBP (Concentration Factor }=10) & 15 \\ 7 & \text { TBP Concentration in Diluent-Washed 2BP Solutions } & 16\end{array}$

\section{LIST OF IGURES}

Page

1 Purex Process

10 


\section{ARALISIS OF RESIDUAL ORGANIC MATERIALS IN AQUEOUS RADIOACTIVE STREAMS FROM THE PUREX PROCESS}

\section{INTRODUCTION}

The Savannah River Plant (SRP) uses the Purex process to recover and purify plutonium and uranium from irradiated natural or depleted uranium nuclear targets.1 The process is a countercurrent solvent extraction process in which $30 \%$ tri-n-butyl phosphate (TBP) dissolved in normal paraffin hydrocarbons (NPH) is used to extract uranium and plutonium from an aqueous nitric acid solution. Both TBP and NPH have good radiolytic and chemical stability and have low aqueous solubility. However, both can contaminate aqueous streams and cause processing difficulties.

This report describes the development of new solid phase extraction methods to allow determination of residual TBP and NPH in aqueous $r$ adioactive streams. Analys is is by gas chromatography (GC).

\section{PURIE PROCESS DESCRIPIIOH}

The major operations of SRP's Purex process are shown in Figure 1. The alum inum jackets of the irradiated target slugs are dissolved in sodium hydroxide and sodium nitrate. The dejacketed slugs are dissolved in nitric acid. The dissolver solution is clarified in Head End to remove silica.

Typical Purex feed contains uranyl nitrate, plutonium nitrate, nitric acid, and fission and neutron activation products. In the first solvent extraction cycle uranium and plutonium are separated from fission products in an 18 stage centrifugal contactor by extraction into $30 \%$ TBP/NPH solvent. Most of the fission products stay with the aqueous phase which is transferred to a high activity waste evaporator.

The solvent from the IA contactor is transferred to mixersettler 1B. Plutonium is reduced to Pu(III) valence and is stripped into the aqueous IBP stream. This is sent to the second plutonium solvent extraction cycle. Uranium dissolved in the solvent is fed to mixer-settler 1C. Uranium is stripped from the solvent into stream lcU with dilute nitric acid.

The aqueous ICU stream is concentrated in an evaporator before going to the second uranium solvent extraction cycle. The uranium is decontaminated further from plutonium and fission products by 


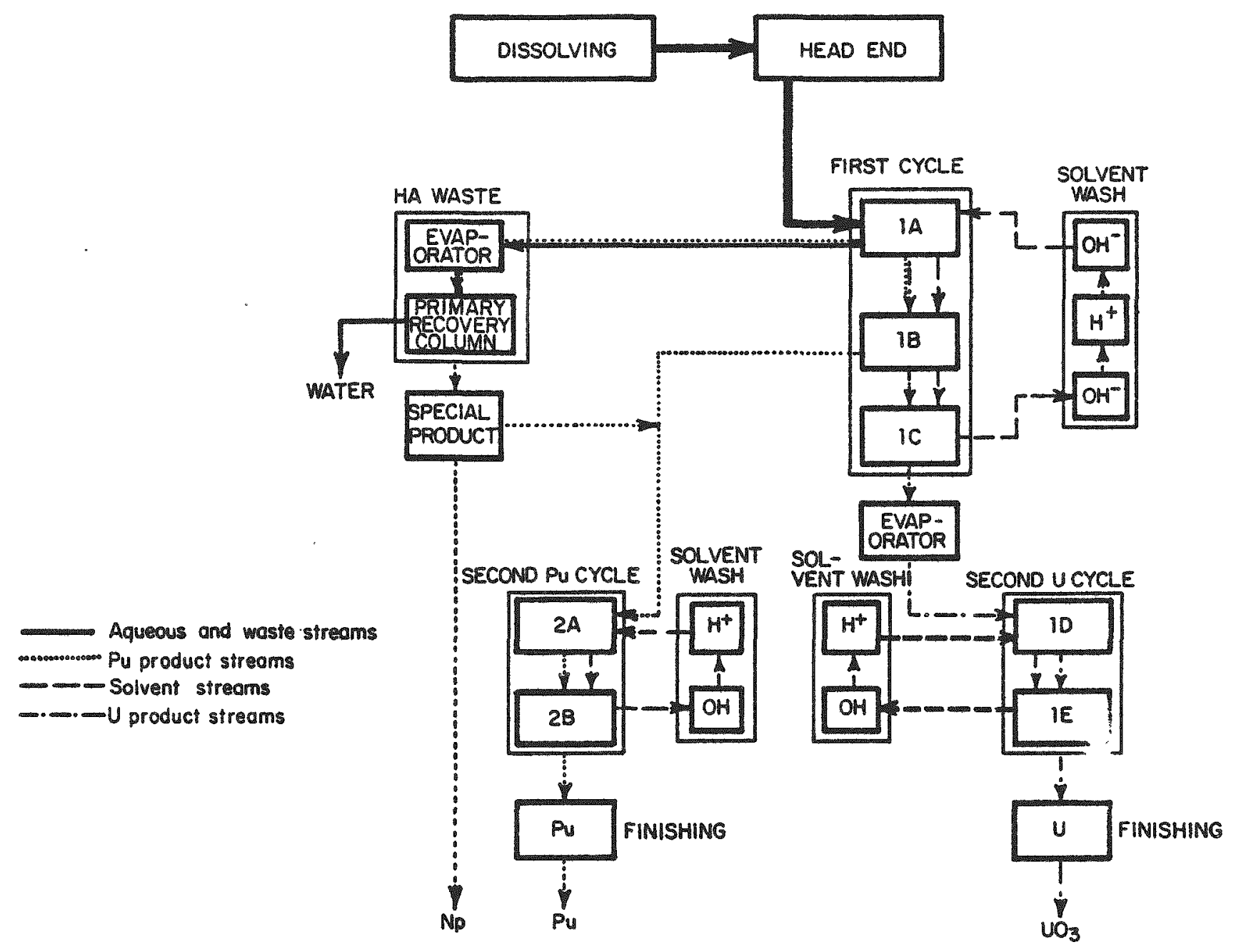

FIGUR 1. Purex Proces 
extracting it into solvent in mixer-settler 1D. The uranium is stripped from the solvent into stream IEU in mixer-settler $1 E$.

In the second plutonium solvent extraction cycle, plutonium is decontaminated further from fission products by extracting it into solvent in mixer-settler 2A. Plutonium is stripped from the solvent in mixer-settler $2 B$. The aqueous plutonium product solution, $2 B P$, is transferred to the plutonium finishing line.

\section{SAMPLING AND BIPERIMERTAL MITIOD}

Weekly composite samples of aqueous waste (evaporator overheads) from the SRP Purex process were obtained (Table 1). Samples of diluent-washed aqueous plutonium product solution (stream 2BP) were also taken (Table 1).

New solid phase extraction methods were developed to allow determination of TBP and NPH in aqueous radioactive streams.

\section{TAEIE 1}

Strean Sampling

\begin{tabular}{lll} 
& Date Sampled & Tank Sampled \\
\cline { 2 - 2 } Composite aqueous waste & $9 / 12 / 86$ & \\
& $10 / 8 / 86$ & - \\
& $10 / 10 / 86$ & - \\
Stream 2BP & $10 / 24 / 86$ & - \\
& $10 / 16 / 86$ & 9.5 \\
& $10 / 16 / 86$ & 9.6 \\
& $11 / 14 / 86$ & 9.5 \\
$11 / 14 / 86$ & 9.8
\end{tabular}

\section{Comporite Aqueou Waste}

The solid phase extraction method uses $1 \mathrm{~mL}$ octadecyl columns (100 mg sorbent). 2 The disposable columns are polypropylene tubes prepacked with $40-\mu \mathrm{m}, 60 \AA$ silica gel particles. Octadecyl (c-18) groups have been bonded to the surface active silanol groups (SiOH).

The column is attached to a vacuum manifold. The column is conditioned by aspirating $2 \mathrm{~mL}$ methanol and then $1 \mathrm{~mL}$ water through the column. The column must not be allowed to dry. 0.5 mi water is added, and a $75 \mathrm{~mL}$ reservoir is attached. $50 \mathrm{~mL}$ of the aqueous waste is slowly passed through the column over a 30-minute period. 
The column is washed with 1 mi water and dried for 2 minutes by aspirating air. The column is then eluted with 3 aliquots ( $400 \mu \mathrm{L}$ each) tetrahydrofuran ( $T H F$ ) to recover the extracted organics. The product is adjusted to $1 \mathrm{~mL}$ for GC analysis.

The concentration factor is 50, and the concentration of the recovered NPH or TBP is multiplied by 0.89 to convert to concentration in water. The NPH concentration is divided by 0.4 , the recovery factor. TBP is quantitatively recovered.

\section{Stream 2BP}

The 1 ml octadecyl column is attached to a vacuum manifold in a glovebox. The column is conditioned by aspirating 2 mi methanol and then $1 \mathrm{~mL}$ water through the column. The column must not be allowed to dry. $0.5 \mathrm{~mL}$ water is added, and a $15 \mathrm{~mL}$ reservoir is attached. 5 ml of the aqueous radioactive solution is slowly passed through the column over a 5 -minute period. The column is washed with $1 \mathrm{~mL}$ water and dried for 2 minutes by aspirating air. The colum is then eluted with 3 aliquots ( $400 \mu \mathrm{L}$ each) tetrahydrofuran (THF) to recover the extracted TBP. The product is adjusted to $1 \mathrm{~mL}$ for GC analysis.

The concentration factor is 5 , and the concentration of the recovered TBP is multiplied by 0.89 to convert to concentration in water. TBP recovery is essentially quantitative.

For 2BP solutions with very low TBP concentrations, $10 \mathrm{~mL}$ can be passed through the column over a 10-minute period. The column is then washed with $2 \mathrm{~mL}$ water to remove interfering material prior to elution with THF. In this case, the concentration factor is 10 .

\section{RESULIS ADD DISCUSSION}

\section{Composite Aqueou Mase}

In order to determine the recovery factor for NPH and TBP in solid phase extraction, we prepared an aqueous solution containing $2.2 \mathrm{ppm}$ NPH and $22.8 \mathrm{ppm}$ TBP. In ten tries with Baker C-18 columas, the mean recoveries of NPH and TBP were $38 \pm 6 \%$ and $98 \pm 4 \%$, respectively (Table 2 ). In ten tries with Supelco C-18 collumes the mean recoveries of NPH and TBP were $40 \pm 6 \%$ and $105 \pm 2 \%$, respectively (Table 3 ). The THF solutions of recovered NPH and TBP were analyzed by GC.

With standard samples in which the solubility of NPH in water ( $>4$ ppm) has been exceeded, recovery is lower with poorer precision. 


\section{TABLE 2}

Recoveries of MPU and TBP with Baker C-18 Colums

\begin{tabular}{llr} 
Run No. & NPH Recovery, $\%$ & TBP Recovery, $\%$ \\
\cline { 2 - 3 } 1 & 37.3 & 91.2 \\
2 & 44.5 & 100.4 \\
3 & 40.5 & 101.8 \\
4 & 44.5 & 100.0 \\
5 & 39.5 & 101.8 \\
6 & 44.5 & 97.4 \\
7 & 39.5 & 99.1 \\
8 & 25.9 & 95.2 \\
9 & 31.4 & 93.0 \\
10 & 36.4 & 103.9
\end{tabular}

TABLE 3

Recoveries of MPE and TBP with Supelco C-18 Columis

\begin{tabular}{lll} 
Run NO. & NPH Recovery, $\%$ & TBP Recovery, $\%$ \\
\cline { 1 - 2 } 1 & 54.5 & 107.9 \\
2 & 27.3 & 101.3 \\
3 & 36.4 & 103.9 \\
4 & 40.9 & 105.7 \\
5 & 40.9 & 104.4 \\
6 & 40.9 & 103.9 \\
7 & 40.9 & 107.5 \\
8 & 40.9 & 103.9 \\
9 & 36.4 & 108.8 \\
10 & 40.9 & 107.0
\end{tabular}


NPH and TBP were identified in composite aqueous waste (Table 4) by GC. TBP concentrations varied from trace amounts to $18.5 \mathrm{ppm}$. NPH was $<1$ ppm. NPH is primarily dodecane, tridecane, and tetradecane and has a characteristic GC elution pattern. The TBP was identified by a match of its GC retention time with that of a known TBP standard in THF.

\section{TABLE}

\section{MPH and TBP Concentration in Composite Aqueous Wast}

$$
\text { Date Sampled TBP, Ppm NPH, PPm }
$$

Composite aqueous waste

$9 / 12 / 86$
$10 / 8 / 86$
$10 / 10 / 86$
$10 / 24 / 86$

$\begin{array}{ll}11.4 & <1 \\ 4.6 & <1 \\ 18.5 & <1 \\ \text { Not detecred } & <1\end{array}$

During development of the solid phase extraction method, we found that methanol elution did not give a good NPH recovery. Elution with hexane did not recover any of the TBP. THF gave a good recovery of both NPH and TBP.

\section{Strean 282}

Residual TBP in stored plutonium product (aqueous 2BP solution) slowly hydrolyzes to dibutyl phosphate (DBR) and n-butyl alcohol. ${ }^{3}$ Plutonium - DBP solids form and cause filter and cation resin bed pluggage in the plutonium finishing line. The soli is also represent a potential nuclear safety hazard. Washing $2 B P$ i 3 NPH diluent prevents solids formation. 3,4 No satisfactory met:- 3 has existed for determining the residual TBP concentration and the quality of $2 B P$ solutions for storage.

We have now developed a solid phase extraction method to analyze residual TBP in diluent-washed $2 B P$ solutions. The rechnique concentrates the TBP and separates it from radioactive species for analysis by GC.

In order to determine the recovery factor for TBP in solid phase extraction, we prepared an aqueous standard solution containing $23.9 \mathrm{ppu}$ TBP. In ten tries with supelco $\mathrm{C}-18$ columns concentration factor $=5$ ), the mean recovery of TBP was $96 \pm 3 \%$ (Table 5). In 10 tries with Supelco $\mathrm{C}-18$ columns (concentration factor $=10$ ), the mean recovery of $\mathrm{TBP}$ was $94 \pm 3 \%$ (Table 6). The THF solutions were analyzed by GC. 


\section{TABLE 5}

\section{Recovery of TBP (concentration factor $=5$ )}

\begin{tabular}{lc} 
Run No. & TBP Recovery,\% \\
\cline { 2 - 2 } 1 & 97.9 \\
2 & 94.1 \\
3 & 93.3 \\
4 & 92.9 \\
5 & 93.3 \\
6 & 94.1 \\
7 & 95.4 \\
8 & 95.4 \\
9 & 100.0 \\
10 & 100.4
\end{tabular}

TABIE 6

Recovery of TBP (concentration factor 10)

Run No.

1

2

3

4

5

6

7

8

9

10
TBP Recovery, \%

97.9

93.3

88.7

91.6

95.4

91.6

93.3

97.5

95.0

95.4 
TBP was recovered from diluent-washed 2BP solutions (Table 7). The TBP was identified by a match of its GC retention time with that of a known TBP standard in THF. TBP concentrations varied from $1.0-3.4 \mathrm{ppm}$. An aqueous standard solution containing 23.9 Ppn TBP was also processed by solid phase extraction (concentration factor $=10$ ). The standard analyzed 21.9 ppm TBP.

\section{TABLE 7}

TBP Concentration in Diluent-Washed 2BP Solutions

\begin{tabular}{llllll} 
& $\begin{array}{l}\text { Date } \\
\text { Sampled }\end{array}$ & $\begin{array}{l}\text { Tank } \\
\text { Sampled }\end{array}$ & $\begin{array}{l}\text { TBP, Ppm } \\
\text { Concentration } \\
\text { Factor }=5\end{array}$ & $\begin{array}{l}\text { TBP, PPm } \\
\text { Concentration } \\
\text { Factor }=10\end{array}$ \\
\cline { 2 - 2 } 2 Stream & $10 / 16 / 86$ & 9.5 & & 3.4 & - \\
& $10 / 16 / 86$ & 9.6 & 1.2 & - \\
& $11 / 14 / 86$ & 9.5 & 1.0 & - \\
$11 / 14 / 86$ & 9.8 & 1.8 & 1.5
\end{tabular}

\section{CONCLUSIONS}

Solid phase extraction is a useful technique to recover organic materials from aqueous radioactive streams from the Purex process. The methods concentrate NPH and TBP and separate them from radioactive species for analysis.

Knowledge of the concentration of organic materials in aqueous waste is useful in assessing impact on pollution control equipment. The storage quality of diluent-washed aqueous plutonium product solution can be determined by a gas chromatographic analysis for residual TBP. 


\section{RITRREMCES}

1. J. M. McKibben. "Chemistry of the Purex Process." Radiochimica Acta 36, 3-15 (1984).

2. 'Baker'-10 SPE Applications Guide, Vol. 1. J. T. Baker Chemical Co., 1222 Red School Lane, Phillipsburg, New Jersey. The Supelco Guide to Solid Phase Extraction, Supelco, Inc., Bellefonte, Pennsylvania.

3. L. W. Gray and G. A. Burney. "A Study of the Formation, Prevention, and Recovery of Plutonium from Phosphate Esters in the Purex Process." Actinide Recovery from Waste and Low-Grade Sources, J. D. Navratil and W. W. Schulz, eds., Harwood Academic Publishers, New York, 309-314. (1982).

4. M. Benedict, T. Pigford, and $H$. Levi. Nuclear Chemical Engineering. Second Edition, McGraw-Hill Book Company, New York, 499-500 (1981). 